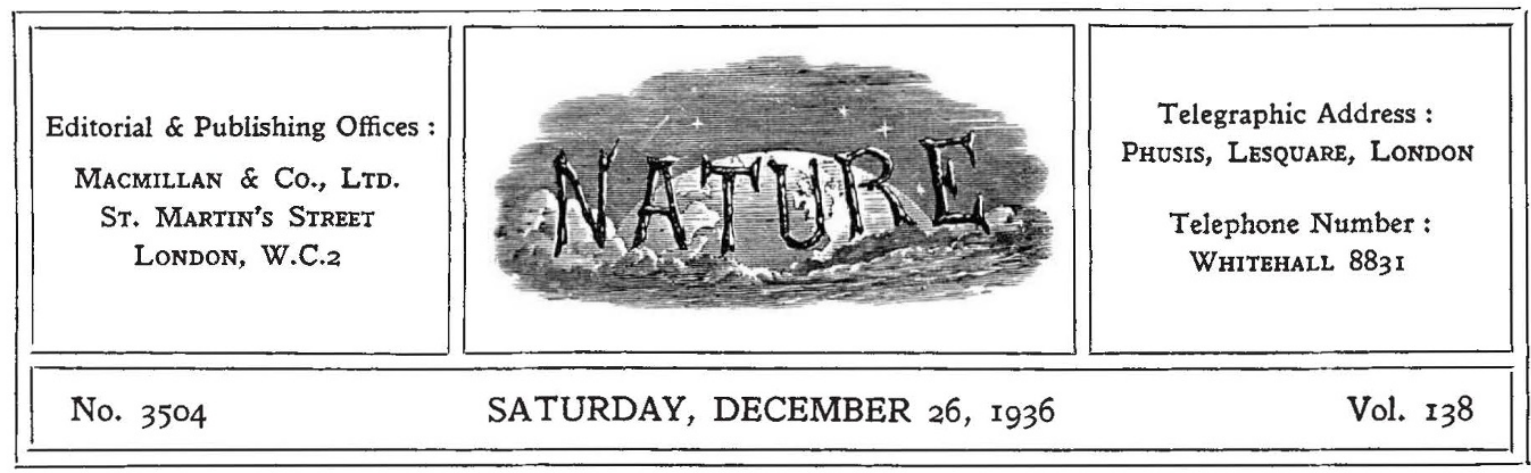

\title{
Rearmament and the League of Nations
}

$A^{L T}$ THOUGH general, but by no means unqualified, support has been given to the Government's programme of rearmament, the impossibility of attaining security in this way alone is fully appreciated by all thoughtful opinion; and much of the support of the Government is conditional upon its efforts to promote collective security and the methods of peaceful change which will diminish the causes of international friction and misunderstanding. Misgivings about the extent of the Government's constructive effort in this field are, however, still apparent.

Unless men are sane enough to recognize that under modern conditions the changed nature of modern warfare makes its renunciation as an instrument of national policy not merely an ideal but also an essential, catastrophe cannot be averted. The most untoward consequence of the present concentration of effort on national rearmament is that it distracts attention from the underlying issues and constructive efforts to find a real basis for peace. Rearmament is at best a counsel of desperation, and no Government to-day has discharged its obligations in the matter of national defence if it has not at the same time explored to the utmost the possibilities not merely of collective defence and security but also of the removal of causes of international friction and of the organization of peace.

The limitations of rearmament, however, are none the less made manifest from time to time, as in the recently published report of the subcommittee of the Committee of Imperial Defence on the vulnerability of capital ships to air attack. While no ship is less likely to be destroyed by air attack than the heavy battleship, the report is on the whole inconclusive. On the high seas, in the main, an air force is still unable to perform the functions of a navy, but the vital question of vulnerability in the narrow seas around the coasts of Great Britain remains undetermined. The subcommittee considers that the day of the capital ship is not over, now or in the near future, but it is clear that while impressed with the vulnerability of the battleship to concentrated air attack under favourable conditions, the Committee merely shrinks from making a decision where the consequences of a mistake might be so serious.

The very inconclusiveness of the report indicates, however, the changed position of Great Britain in regard to defence. Its insularity has gone for ever, and now the ability of the Navy to perform its time-honoured functions can be called in question without instant refutation. Moreover, evidence provided by such a report is very welcome as coming from those the sincerity of whose efforts to secure effective defence cannot be questioned.

This is, in fact, one of the most untoward consequences of the political discussion of rearmament. There is a disposition to assume that those who doubt or deny the possibility of effective aerial or naval defence under modern conditions are anxious to commit the country to the opposite policy of pacificism, and to overlook the extreme dangers which Fascism and militarism offer to the best in man's heritage to-day. Accordingly, Mr. Jonathan Griffin's "Alternative to Rearmament"* is to be welcomed as a vigorous demonstration of a constructive alternative policy which should commend itself to a great body of moderate opinion in Great Britain which, while convinced of the necessity of improving defence, is indis-

* Alternative to Rearmament. By Jonathan Griffin. Pp. xii +215. (London: Macmillan and Co., Ltd., 1936.) 6s. net. 
posed to afford the militarists carte blanche and realizes that rearmament alone can offer no solution.

Mr. Griffin is under no illusions as to the consequences of rearmament, and quotes comprehensively from authorities to demonstrate the extreme vulnerability of Great Britain to air attack, and the impossibility of any really effective defence. He does not, however, urge that the only policy is one of developing our air forces so as to be capable of rendering instant and equally heavy reprisals. On the contrary, he argues convincingly that to rearm with bombers in this fashion would almost certainly precipitate conflict, and he urges accordingly that our policy should be to concentrate on the measures which would make this country less vulnerable but which would not be construed as a threat to other countries.

On the question of defence without menace, Mr. Griffin makes numerous constructive proposals. He questions the utility of those air-raid precautions which undermine liberty, such as masks and drills, which he stigmatizes as deception, not defence. He urges instead the duplication, dispersal and protection of essential public services and buildings; development of fire-fighting services; exploration of the possibilities of searchlights; the rebuilding or evacuation of great towns; the development of anti-aircraft guns ; provision of fighting planes instead of bombers, and above all the adequate organization of the storage of food. If we could store a year's food supply, we should be freed from dependence on the doubtful ability of the Navy to fill its old functions, and in this we should be offering no menace to other countries.

The defence policy advocated thus aims at saving life, not at maintaining morale, and it is insisted that we should avoid measures involving education of the public in passive defence as much as that the policy outlined should be used as an alternative to rearmament. Rearmament should only be permitted on the condition that menacing armaments are definitely limited and co-ordinated for collective security; that there should be no provocation except sanctions against an aggressor ; no commitments except the Covenant of the League and a Europe-wide system of collective security against aggression from the air.

On many of these points it is clear that $\mathrm{Mr}$. Griffin is already assured of the support of scientific workers who have devoted attention to this question, and his statement is to be commended to the growing number of scientific workers who are concerned about the prostitution of scientific effort for war purposes and look for some solution which offers a chance of constructive effort for peace and security, and who are prepared to take trouble to sift out the facts from the prejudices in which they are so often embedded.

Many of Mr. Griffin's arguments are underlined in the restatement by Lord Davies of views on the relations of force and law in the light of the unhappy experience of the Italo-Abyssinian conflict*. While he contributes little that is new, Lord Davies, without dwelling unduly on the mistakes of the past, emphasizes the steps which can and must be taken to prevent a like outrage again endangering the foundations of our common security and order. No reader of this book can be blind to the mistakes which Great Britain, though not this country alone, has made, and its failure to render wholehearted and unambiguous support of the collective principle at decisive moments.

Here again is the constructive and practical outlook which scientific workers should welcome. The case for federation and an international police force is set forth with an urgency and relevance which are fresh and effective, even to those familiar with Lord Davies's earlier books. Notably is this true of his discussion of the reform of the League, the present ineffectiveness of which he attributes, after the reluctance of certain powerful members to use the machinery already existing, to the absence of federation in Europe. A new and reformed League must be based on an impartial exploration of the possibilities of the federal system in Europe. Much indeed could be done within the framework of the present Government, and the book contains trenchant criticism of the premature judgment passed on the sanctions system from an experience of its very limited and partial application.

Like Mr. Griffin's book, "Nearing the Abyss" is a challenge to further thought and investigation on vital matters while yet there is time, and both books will indicate fields in which the help of scientific workers is welcome if not essential. Equally impressive is the plea which Mr. C. R. Buxton has recently entered $\dagger$ for an exploration of the possibilities and mechanism of peaceful change in such fields as access to raw materials, population, mandates and the like.

* Nearing the Abyss: the Lesson of Ethiopia. By Lord Davies. Nearing the Abyss: the Lesson of Ethiopia. By Lord Davies.
Pp. xilit+182. (London: Constable and Co., Ltd., 1936.) 38. 6d. net. $\uparrow$ The Alternative to War : a Programme for Statesmen. By C. $\mathbb{R}$. Buxton. Pp. 176. (London: George Allen and Unwin, Ltd., 1036.) 48. $6 d$. net. 
Scientific workers who will take the trouble to examine the material now available, in these three books and elsewhere, cannot fail to realize how wide is the field awaiting the application of the scientific spirit and the scientific method, or to find some section of the field in which their own contribution might be made to national defence and security, and the development of that educated opinion upon which alone all constructive effort must rest.

\section{Ancient Buildings in Scotland and England}

$\mathrm{T}^{\mathrm{H}}$ HE discussion which took place in the House of Lords on December 2, when the question was raised as to the preservation of ancient structures in Scotland and England, while achieving little in the way of immediate action, the motions upon which debate arose being by leave withdrawn, was far from abortive. It served emphatically to direct public attention to an irretrievable loss of material of historic or æsthetic value, especially in Scotland, and in the replies elicited from the representatives of the Government, afforded hope of official support and co-operation in the efforts which are being made to avert further destruction, even though the prospects of financial assistance from the Treasury are not encouraging.

The debate was, perhaps, most useful in clearing the way for further action and in suggesting lines along which further effort might be directed. The problems in the two countries, though very similar, are not identical. Whereas in England the question before the House was concerned only with structures of the eighteenth century, in Scotland material surviving from the whole historic period is affected. In both instances, however, the structures are not 'historic' in the technical sense, or 'country houses', but examples of humbler domestic architecture - a class of building which in both rural and urban areas is of special importance for the cultural history of Scotland, where the strongly marked individuality of the people clearly has been affected distinctively by environmental influences. It was pointed out by Lord Hamilton of Dalzell and other members of their Lordships' House, who supported him, that during the last few years destruction has been taking place in Scotland wholesale and at an extremely rapid rate. "Old Scotland," said Lord Crawford, "is vanishing before our eyes."

The tragedy of this destruction lies in the fact that so often it is avoidable, but is justified as a public improvement, or amelioration of social conditions-road-making or widening and the improvement or extension of housing accommodation for the poorer classes. In Scotland, more especially, Government financial assistance has been made available in a form which has acted as a spur to the destructive activities of local authorities, while the private owner, suffering under a public burden in the form of rates-payable in Scotland on empty property-has sought relief from an expense without return.

In his sympathetic reply on behalf of the Government, Lord Strathcona pointed out methods by which complete destruction of buildings worth preservation might be avoided without forfeiting assistance from the Treasury in certain classes of property, and indicated the extent of departmental supervision already exercised in endeavouring to secure that no historically interesting building should be demolished. The financial obligation, however, involved in any promise of financial assistance from the Government towards the cost of preservation is an uncertain factor, and the delay for which Lord Strathcona asked until the information now being collected by the National Trust is available, though unfortunate, is not unreasonable.

The First Commissioner of Works (Lord Stanhope), in dealing with the position of the eighteenth-century house in England, was less sympathetic, and in suggesting that effort should be directed to persuasion of the local authority, upon whom he sought to throw responsibility, he ignored past experience. For their notorious shortcomings in such matters, local authorities are not entirely to blame; and the time has surely come when the public may be regarded as sufficiently instructed in the value of its ancient treasures to accept the overriding verdict of a Department which speaks with full scientific and technical knowledge. The powers of the Office of Works as a protector of ancient structures should be enlarged to cover in some measure inhabited or habitable structures not contemplated in existing provision. 